\title{
Evaluasi Teknik-Ekonomi Perontok Pokem (Setaria italica L.) Mekanis
}

\section{Technical-Economic Evaluation of the Machanical Pokem (Setaria italica L.) Thresher}

\author{
Paulus Payung $^{1}$, Abadi Jading ${ }^{2}$, Reniana ${ }^{3}$ \\ 1,2,3 Jurusan Teknologi Pertanian Universitas Papua, \\ Jl. Gunung Salju Amban Manokwari-Papua Barat kode Pos 98314 \\ *Email: p.payung@unipa.ac.id
}

\begin{abstract}
Postharvest processing of Pokem, especially at the threshing stage, is still done conventionally / traditionally so that this method is very complicated, less efficient and has limited capacity. The purpose of this study is to evaluate the techniques of mechanical punchers. The test results obtained an average threshing capacity of $17.60 \mathrm{~kg} / \mathrm{hour}$, the average threshing efficiency was $86.80 \%$, and the average percentage of panicle separation was $96.40 \%$. Financial evaluation results obtained by Net Present Value $(N P V)=R p .20,317,066$, Net Benefit-Cost Ratio $(B / C)=2.49$, Internal Rate Return $($ IRR $)=64 \%$ and Pay Back Period $(P B P)=1.5$ years. Based on the financial analysis, the use of thresher is feasible.
\end{abstract}

Keywords: Pokem, local food, prototype, mechanical thresher, evaluation

\begin{abstract}
Abstrak
Pengolahan pascapanen pokem khususnya pada tahapan perontokan masih dikerjakan secara konvensional/tradisional sehingga cara ini sangat rumit dan kurang efisien serta kapasitas yang terbatas. Tujuan penelitian ini adalah melakukan evalusi teknik-ekonomi alat perontok pokem mekanis . Hasil pengujian diperoleh rata-rata kapasitas perontokkan 17,60 kg/jam, rata-rata efisiensi perontokan $86,80 \%$ dan rata-rata persentase pemisahan malai $96.40 \%$. Hasil evaluasi finansial diperoleh Net Present Value $(N P V)=$ Rp. 20,317,066, Nett Benefit-Cost Ratio $(\mathrm{B} / \mathrm{C})=2,49$, Internal Rate Return $(I R R)=64 \%$ dan Pay Back Period $(P B P)=1,5$ tahun. Berdasarkan analisis finansial maka penggunaan alat perontok ini layak.
\end{abstract}

Kata kunci: pokem, pangan lokal, prototipe, perontok mekanis, evaluasi.

\section{PENDAHULUAN}

Pokem (Setaria italica. L) yang sering sebut gandum Papua merupakan salah satu jenis tumbuhan lokal (endemik) Papua, khususnya di Kabupaten Biak Numfor (Rauf dan Lestari, 2009). Pokem telah dimanfaatkan sebagai makanan kesehatan bagi ibu hamil, makanan tambahan anak balita, dan lain-lain karena mempunyai nilai gisi khususnya kabohidrat yang tinggi (Suharno, et al. 2015). Pokem juga dapat dimanfaatkan untuk kebutuhan hidup rumah tangga, bahan baku indutri pengolahan makanan dan sektor-sektor lainnya (Dimara, 2008).
Kandungan karbohidrat pada pokem (Setaria italica. L) lebih tinggi yaitu sebesar $74,16 \%$ bila dibandingkan dengan gandum pada umumnya (Budi, 2003). Pokem juga memiliki keunggulan antara lain mudah dibudidayakan, memiliki hasil produksi cukup tinggi, mampu tumbuh pada tanah kering maupun dalam kondisi tergenang serta mempunyai daya adaptasi cukup tinggi terhadap lahan marginal. Zooleh,, et al. (2011) melaporkan bahwa pokem (seteria italica. L) dapat tumbuh bebas dilahan kering tanpa tergantung pada pengairan/irigasi yang memadai. Selain itu, menurut Rauf, et al. (2009) pokem dapat tumbuh pada hampir 
semua jenis tanah termasuk tanah kurang subur, tahan kekeringan serta memiliki umur panen pendek dan kegunaannya beragam.

Sesuai dengan pengamatan di lapangan masalah serius kaitannya dengan pengembangan pokem di Papua adalah masalah teknologi pasca panen yakni terbatasnya peralatan pascapanen.Teknologi pascapanen pokem sangat penting bagi masyarakat karena jenis tanaman ini menghasilkan ukuran biji yang sangat kecil dengan diameter 1 sampai $1,2 \mathrm{~mm}$, sehingga memerlukan penanganan secara khusus agar kualitas tepung yang dihasilkan lebih baik. Pengolahan pascapanen pokem oleh masyarakat di Papua masih menggunakan cara yang sangat sederhana atau konvensional, karena belum tersedianya peralatan dan mesin pascapanen yang lebih baik, sehingga faktor inilah yang menyebabkan masyarakat tidak serius membudidayakan pokem (Payung dan Padang, 2012).

Dalam mengoptimalkan proses penanganan pascapanen pokem, maka diperlukan ketersediaan peralatan yang dapat bekerja lebih cepat, efisien, serta mudah dioperasikan oleh masyarakat. Dalam penelitian ini dilakukan evaluasi teknoekonomi dari alat perontok mekanis yang telah dirancang sebelumnya dengan mengadopsi peralatan perontok bijian-bijian diantaranya lada (Risfaheri, et al. 1999). Dengan adanya hasil pengujian teknikekonomi dari alat perontok ini, diharapkan dapat menjadi bahan informasi bagi masyarakat dan stacholder mengenai kemungkinan penggunaan alat perontok mekanis dalam penanganan pasca panen pokem untuk peningkatan produksi pokem.

\section{METODOLOGI}

\section{Waktu dan Tempat}

Perancangan dan evaluasi teknik perontok pokem dilaksanakan di Workshop Teknologi Pertanian Universitas Papua sedangkan penelitian lapangan untuk data analisis finansial dilaksanakan di Pulau Numfor Kabupaten Biak-Numfor Provinsi Papua pada bulan Mei - November 2017.

\section{Bahan dan Alat}

Bahan dan alat yang digunakan dalam pernelitian ini adalah: Alat perontok pokem mekanis, pokem bermalai, timbangan, stopwath, alat tulis menulis dan peralatan pendukung lainnya

\section{Tahapan Penelitian}

Penelitian ini dilakukann dengan dengan tahapan sebagai berikut:

1. Persiapan Bahan Perontok Pokem Mekanis

Alat perontok pokem yang evaluasi adalah hasil rancangan penelitian tahun sebelumnya. Fungsi alat perontok ini untuk merontokkan atau memisahkan biji pokem dari malainya yang digerakkan dengan motor bakar (Honda 5,5 hp). Mekanisme kerja alat ini adalah dengan prinsip malai pokem dimasukkan ke dalam saluran pemasukan (hopper) dan malai pokem di hantam oleh gigi perontok. Gigi perontok dipasang pada permukaan silinder perontok yang digerakan secara mekanis dengan sistim puli dan sabuk. Bagian-bagian dari alat rancangan ini terdiri dari beberapa komponen yang saling menopang satu dengan lain sehingga membentuk suatu sistem sebagai perontok biji pokem mekanis seperti yang diperlihatkan pada Gambar.1.

2. Pelaksanaan Penelitian

Penelitian ini dilakukan dengan tahapan sebagai berikut: a) menimbang bobot pokem sebelum dirontokkan dengan alat perontok mekanis, b) mengamati waktu yang digunakan untuk perontokan. c) menimbang bobot biji pokem yang terontok setelah proses perontokan d) menimbang bobot biji pokem yang tidak terontok oleh alat perontok mekanis (biji pokem yang tidak terontok dilanjutkan dengan perontokkan manual). menimbang bobot malai yang keluar melalui saluran malai. Pada penelitian ini pengulangan dilakukan sebanyak 5 kali.

3. Evaluasi Teknik Perontok Pokem

Parameter yang diamati adalah efisiensi perontokan (\%), persentase pemisahan malai (\%), dan kapasitas perontokan (kg/jam). Efisiensi perontokkan dan persentase pemisahan malai dihitung dengan formulasi sebagai berikut: 
Keterangan :

B1 : Bobot biji pokem yang terontok $(\mathrm{kg})$

B2 : Bobot biji pokem yang tidak terontok $(\mathrm{kg})$

M1: Bobot malai yang keluar pada pada keluaran malai $(\mathrm{kg})$

M2: Bobot malai yang terbaawa pada keluaran bijian $(\mathrm{kg})$

$\mathrm{T}$ : Waktu (jam)

\section{Analisis Finansial}

Untuk mengetahui kelayakan finansial maka dilakukan analisis kelayakan berdasarkan kriteria-kriteria yang digunakan dalam melakukan suatu evaluasi terhadap investasi proyek berpedoman pada Husnan dan Suwarsono (1997) yaitu: (1) NPV (Net Present Value) adalah metode untuk menghitung selisih antara nilai sekarang investasi dengan nilai sekarang penerimaanpenerimaan kas bersih (operasional maupun terminal cash flow) di masa yang akan datang. Jika NPV lebih besar dari nol maka proyek layak untuk dilaksanakan sebaliknya jika lebih kecil dari nol tidak layak untuk dilaksanakan. (2) IRR (Internal Rate off Return) adalah tingkat diskonto pada saat NPV sama dengan nol dan dinyatakan dalam persen. Proyek dinyatakan layak apabila nilai IRR lebih tinggi dari suku bunga yang berlaku. (3) Net B/C (Net Benefit-Cost Ratio) Net Benefit Cost Ratio merupakan angka perbandingan antara jumlah PV yang bernilai positif dengan jumlah PV yang bernilai negatif. Kriteria kelayakan proyek adalah jika Net B/C lebih besar sama dengan satu dan tidak layak jika Net B/C kurang dari satu. (4) Pay Back Period (PBP) Pay back period merupakan kriteria tambahan dalam analisis kelayakan untuk melihat periode waktu yang diperlukan dalam melunasi seluruh pengeluaran investasi..

Dalam Analisis finansial perontok pokem perlu ditunjang dengan data pasaran. Data pasaran yang digunakan harga-harga yang ada di lapangan (Biak-Numfor) dimana pokem bermalai Rp.20.000 per $\mathrm{kg}$ dan biji pokem (pokem yang telah terontok) harganya rata-rata Rp. 35.000 per kg.

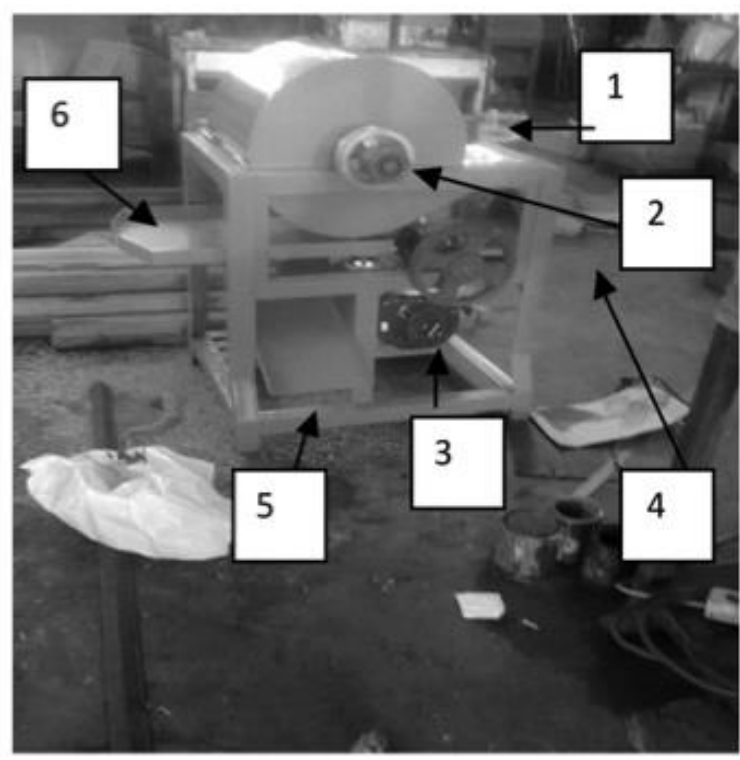

Keterangan gambar

1. Saluran Input Bahan

3. Motor penggerak

5. Saluran biji pokem terontok

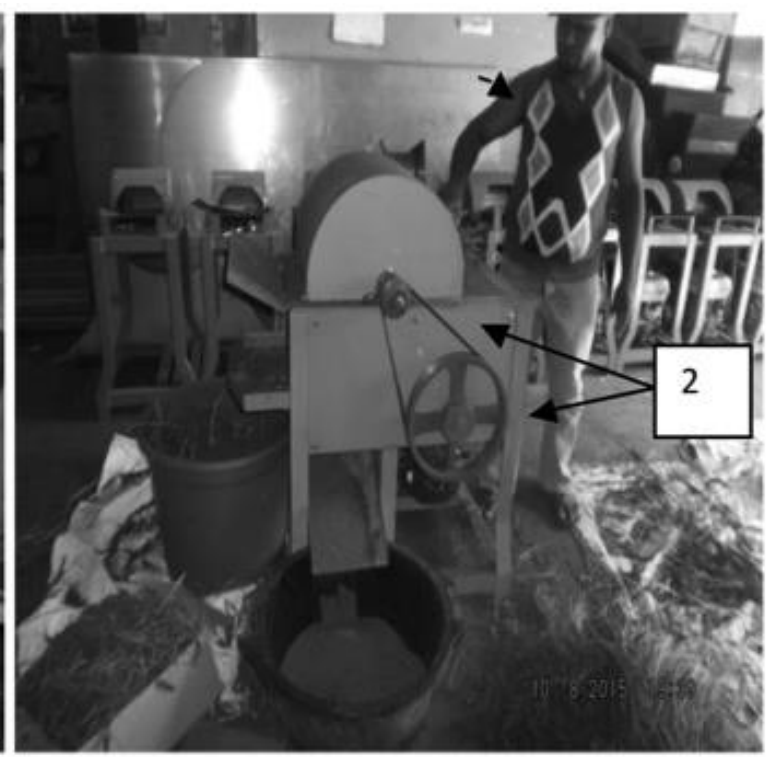

2. Transmisi sistim puli dan sabuk

4. Kerangka

6. Saringan berputar

Gambar 1. Prototipe alat perontok pokem 


\section{HASIL DAN PEMBAHASAN}

\section{Evaluasi Teknik Perontok Pokem \\ Kapasitas perontokan}

Kapasitas perontontokan yaitu bobot biji pokem yang terontok per waktu perontokan. Rata-rata kapasitas yang diperoleh diperlihatkan pada Tabel 1. Pengujian dilakukan 5 kali ulangan dengan bobot bahan dan waktu perontokan yang berbeda-beda. Berdasarkan Tabel 1, rata-rata kapasitas perontokan yang diperoleh adalah $17,60 \mathrm{~kg} / \mathrm{jam}$. Kapasitas dari alat ini masih terbatas jika dibandingkan dengan perontokkan gandum yang sejenis dengan pokem, di mana kapasitas perontokan gandum rata-rata 155 $\mathrm{kg} / \mathrm{jam}$ (Firmansyah et al. 2010). Keterbatasan kapasitas ini diakibatkan oleh faktor fisik/karakteristik yakni ukuran biji pokem yang sangat kecil bila dibandingkan dengan gandum lainnya, di mana ukuran diameter gandum rata-rata $2 \mathrm{~mm}$ sedangkan ukuran diameter pokem sangat kecil 1-1.2 mm (Anonim. 2017).

Sebaliknya, jika dibandingkan dengan perontok pokem manual yang telah dirancang sebelumnya kapasitas yang diperoleh dengan alat ini lebih besar yang hanya berkapasitas $6,54 \mathrm{~kg} / \mathrm{jam}$ (Istalaksana dan Payung. 2013). Hasil pengamatan di lapangan (Numfor) tahun 2009 rata-rata kapasitas perontonkkan dengan cara manual adalah 1-2 kg/jam (Payung, ddk. 2009). Sehingga bila dibandingkan dengan hasil perontokkan manual di lapangan maka alat perontok pokem mekanis ini kapasitasnya jauh lebih tinggi.

Tabel 1. Rata-rata kapasitas perontokkan dengan alat perontok mekanis

\begin{tabular}{cccc}
\hline Ulangan & pokem terontok $(\mathrm{kg})$ & waktu $($ jam $)$ & Kapasitas Perontokan $(\mathrm{kg} / \mathrm{jam})$ \\
\hline 1 & 6.20 & 0.30 & 20.67 \\
2 & 5.22 & 0.25 & 20.88 \\
3 & 5.00 & 0.32 & 15.79 \\
4 & 3.33 & 0.22 & 15.37 \\
5 & 4.85 & 0.32 & 15.32 \\
\hline \multicolumn{4}{r}{} \\
\hline
\end{tabular}

\section{Efisiensi perontokan}

Efisiensi perontokan merupakan suatu parameter yang digunakan menentukan kinerja alat perontok, semakin tinggi efisiensi perontokan semakin baik kinerja dari alat tersebut. Rata-rata Efisiensi perontokan dari alat perontok ini diperlihatkan pada Tabel 2.

Berdasarkan Tabel 2 . rata-rata efisiensi perontokan yang hasilkan dari alat ini adalah $86.80 \%$. dari kisaran efisiensi ini menandahkan bahwa masih ada sekitar $13.20 \%$ yang belum terontok. Hal ini dipengaruhi faktor karakteristik dari pokem itu sendiri dengan ukuran biji yang sangat kecil dan malai pokem mudah patah karena faktor kekeringan (Ka 12\%) sehingga tidak terontok secara total. Selain itu efisensi perontokan ini dipengaruhi oleh jarak gigi perontok yang berjarak cukup jauh yakni $10 \mathrm{~cm}$ cukup jauh dan panjang gigi perontok yang masih masih pendek, jika dibandingkan dengan jarak gigi perontok gabah yang idealnya berjarak $5 \mathrm{~cm}$ dan dan panjang gigi perontok 6-7 $\mathrm{cm}$ (Firmansyah,I.U. 2011)

Tabel 2. Rata-rata efisiensi perontokan biji Pokem dengan perontok mekanis

\begin{tabular}{cccc}
\hline Ulangan & terontok $(\mathrm{kg})$ & tidak terontok $(\mathrm{kg})$ & esisinsi perontokan $(\%)$ \\
\hline 1 & 6.20 & 0.90 & 87.32 \\
2 & 5.22 & 0.90 & 85.29 \\
3 & 5.00 & 0.85 & 85.47 \\
4 & 3.33 & 0.50 & 86.95 \\
5 & 4.85 & 0.60 & 88.99 \\
\hline \multicolumn{2}{r}{} \\
\hline
\end{tabular}




\section{Persentase pemisahan malai}

Persentase pemisahan malai merupakan jumlah malai yang keluar dari saluran pengeluaran malai dari alat rancangan dibagi dengan total malai dalam satu kali proses perontokan. Rata-rata pemisahan malai yang diperoleh diperlihatkan pada Tabel 3.

Pada Tabel 3. Rata-rata persentase pemisahan malai dari alat rancangan ini adalah $96,4 \%$, hal ini mengindikasikan bahwa proses permisahan malai cukup bagus. Prinsip pemisahan malai dari alat ini adalah dengan sistim ayakan yang digerakan oleh motor penggerak yang diturunkan dari as silinder perontok. Ketidaksempurnaan pemisahan malai ini diakibatkan masih adanya sela-sela antara dindng pengupas dengan ayakan sehingga dapat dilalui oleh potongan malai yang kecil. Untuk memperkecil lolosnya malai melalui sela tersebut maka perlu dilapisi lapisan karet dengan tetap memperhitungkan kelancaran pergerakan saringan.

Tabel 3. Persentase pemisalahan malai dari pengujian alat perontok pokem

\begin{tabular}{cccc}
\hline Ulangan & $\begin{array}{c}\text { malai yang keluar } \\
\text { bersama biji } \\
\text { pokem }(\mathrm{kg})\end{array}$ & $\begin{array}{c}\text { malai yang keluar dari } \\
\text { saluran malai } \\
(\mathrm{kg})\end{array}$ & persentase pemisahan malai $(\%)$ \\
\hline 1 & 0.14 & 4.38 & 97 \\
2 & 0.18 & 4.21 & 96 \\
3 & 0.18 & 4.30 & 96 \\
4 & 0.11 & 3.56 & 97 \\
5 & 0.18 & 4.38 & 96 \\
\hline
\end{tabular}

\section{Analisis Finansial}

Analisis finansial suatu proyek bertujuan untuk mengkaji kelayakan suatu proyek dalam mengambil keputusan layak tidaknya proyek tersebut dikerjakan.

Dalam analisis finansial alat ini menggunakan beberapa asumsi-asumsi sebagai berikut : Harga yang digunakan dalam perhitungan adalah harga konstan pada tahun pertama, Biaya perawatan tiap tahun tetap yaitu 5 persen dari biaya pembuatan alat perontok pokem, biaya perbaikan pada akhir umur ekonomis alat yaitu sebesar 20 persen, Penyusutan dihitung dengan garis lurus, nilai sisa diasumsikan $25 \%$ dari nilai awal dan faktor diskonto sebesar 17 persen.

Berdasarkan cash flow dapat dianalisis kelayakan investasi penggunaan alat perontok pokem yang meliputi NPV, PBP, IRR, Net B/C ratio. Hasil Analisis kelayakan beberapa kriteria ditunjukkan pada Tabel 4.

Tabel 4. Kriteria-kriteria inventasi alat perontok pokem

\begin{tabular}{llll}
\hline \multicolumn{4}{c}{ Kriteria Inventasi } \\
\hline NPV (Rp) & IRR $(\%)$ & BCR & PBP (thn) \\
\hline $20,317,066$ & 56 & 2.49 & 1.5 \\
\hline
\end{tabular}

Nilai NPV pembuatan perontok pokem dengan discount faktor $17 \%$ adalah sebesar Rp $20,317,066$ 18. Nilai ini menunjukkan bahwa hasil bersih (net benefit) yang diterima dengan nilai sekarang adalah sebesar Rp 20,317,066. NPV menunjukkan angka positif, sehingga penggunaan alat perontok dinyatakan layak.

Payback Periodi (PBP) merupakan salah satu metode perhitungan Capital Budgeting yang relatif sederhana. Metode ini merupakan penentuan jangka waktu yang dibutuhkan untuk menutup initial investment dari suatu investasi proyek dengan menggunakan cash inflow yang dihasilkan investasi tersebut. PBP dari investasi ini adalah 1,5 tahun artinya investasi ini telah tertutupi pada 1,5 tahun.

Net Benefit Cost Ratio (Net B/C) merupakan nilai perbandingan antara NPV yang bernilai positif dengan NPV yang bernilai negatif. Apabila nilai Net B/C lebih besar dari 1 (satu), maka investasi layak untuk dilaksanakan. Nilai net $B / C$ pembuatan perontok pokem ini adalah sebesar 3,71 sehingga investasi dinyatakan layak. 
Internal Rate of Return (IRR) adalah suatu nilai suku bunga yang membuat NPV investasi sama dengan nol, atau tingkat bunga yang menunjukkan jumlah nilai sekarang netto (NPV) sama dengan jumlah seluruh ongkos investasi. Nilai IRR investasi pembuatan perontok pokem adalah sebesar $56 \%$. Nilai ini lebih tinggi dari suku bunga yang berlaku, yaitu $17 \%$, sehingga investasi dinyatakan layak. Berdasarkan nilai-nilai kriteria yang diperoleh maka penggunaan alat perontok ini layak atau menguntungkan.

\section{KESIMPULAN}

Rata-rata kapasitas perontokan yang didapatkan adalah $17.60 \mathrm{~kg} / \mathrm{jam}$, rata efisiensi perontokan $86.80 \%$ dan rata-rata persentase pemisahan malai sebesar $96,40 \%$, sedangkan berdasarkan analisis finansial penggunaan alat ini layak berdasaran kriteria Net Present Value (NPV) ), Internal Rate off Return (IRR)) dan Net Benefit-Cost Ratio (B/C) dan Pay Back Period (PBP) selama 1,5 tahun.

\section{REFERENSI}

Anonimus. Jewawut Kaya Kandungan Gisi, Badan Litbang Pertanian. http://www.Litbang Pertanian.go.id. Diakses : 23 November 2018, Jam 16.10 .

Budi, L., (2003), Pemanfaatan Gandum Papua (Pokem) sebagai Sumber Pangan Alternatif untuk Menunjang Ketahanan Pangan Masyarakat Papua. Prosiding Lokakarya Pangan Spesifik Lokal Papua. Jayapura, 20-21 Desember 2003, pp. 121-127.

Dimara, L., (2008), Studi Pokem (Gandum Numfor) sebagai Bahan Pangan dan Sumber Vitamin A Alternatif bagi Masyarakat Papua. Prosiding Seminar Nasional Pengembangan Agroindustri Berbasis Sumberdaya Lokal untuk Mendukung Ketanahanan Pangan. Universitas Brawijaya, Malang, 14 Agustus 2008, pp. 156-163.

Firmansyah, I.U., (2013), Penekanan kehilangan hasil pada proses perontokan gandum. Prosiding Seminar Nasional Serelia. Institut Pertanian Bogor, 20 Agustus 2013, pp. 550-557.
Husnan, S., Suwarsono., (1997), Studi Kelayakan Proyek, UPP AMP YKPN, Yogyakarta.

Istalaksana, P., Payung, P., (2013), Rancang Bangun dan Evaluasi TeknoEkonomi Alat Perontok Pokem (Setaria italica). Jurnal Teknologi Pertanian, Vol. 14 (3), pp. 209-214.

Payung, P., Jading, A., (2009), Desain dan Analisis Finansial Pengendali logika Fuzzy pada Alat Pengering Pokem (Gandum Papua) Model Cross Flow Fluidazed Bed Secara Kontinyu. Laporan Penelitian Hibah Bersaing, UNIPA, Manokwari.

Payung, P., Padang, E., (2012), Rancang Bangun dan Unjuk Kerja Alat Perontok dan Pengupas Pokem (gandum Papua) Tepat guna untuk Produksi Tepung Pokem di Papua. Laporan Penelitian Stategis Nasional, UNIPA, Manokwari.

Risfaheri, T., Hidayat., (1999), Rancang Bangun Alat Perontok Lada dengan Penggerak Engkol Untuk Pengolahan Lada Hitam. Jurnal LITRI, Vol 5(2), pp. 63-69.

Rauf, W.A., Lestari, S.L., (2009), Pemanfaatan Komoditas Pangan Lokal sebagai Sumber Pangan Alternatif di Papua. Jurnal Litbang Pertanian, Vol 28 (2): pp. 187-193.

Suharno, Supeni, S., Verena. A., dan Tanjung, R.H.R. (2015), Usaha Domestifikasi Tumbuhan Pokem (Setaria italica L) Masyarakat Lokal Pulau Numfor, Kabupaten Biak Numfor sebagai Upaya Menunjang Ketahanan Pangan Nasional. Jurnal Manusia dan Lingkungan, Vol 22 (1), pp. 73-83.

Zooleh, H. H., Jahansooz, M.R., Yanusa, I., Hosseini, S.M.B., Chaichi, M.R., Jafari, A.A. (2011), Effect of Alternate Irrigation on root-devided Foxtail Millet (Setaria italic). Australian Journal of cross Science, Vol 5(2), pp. 205-213. 